\title{
Corporate Governance and Earnings Management: Jordanian Evidence
}

\author{
Suzan Abed \\ Faculty of Economic and Administrative Science, Accounting Department \\ Applied Science University, Jordan-Amman 11931 \\ Tel: 96-26-560-9999 Ext. $1383 \quad$ E-mail: s_abed@asu.edu.jo
}

Ali Al-Attar

Faculty of Economic and Administrative Science, Accounting Department

American University of Madaba, Jordan-Amman 11821

Tel: 96-26-5554-8230 Ext. 1376 E-mail: alimms29@yahoo.com

Mishiel Suwaidan

Faculty of Economic and Administrative Science, Accounting Department

Yarmouk University, Jordan-Irbid 21163

Tel: 96-22-721-1111 Ext. 2489 E-mail: msuwaidan@yu.edu.jo

\author{
Received: August 2, 2011 \\ Accepted: September 9, $2011 \quad$ Published: January 1, 2012 \\ doi:10.5539/ibr.v5n1p216 \\ URL: http://dx.doi.org/10.5539/ibr.v5n1p216
}

\begin{abstract}
This study examines the relationship between earnings management and characteristics of corporate governance mechanism for a sample of Jordanian non-financial firms during the period 2006-2009. Earnings management is measured by discretionary accruals using Jones models. The characteristics examined are the existence of independence members within the board of directors, the size of the board of directors, the role duality (CEO/chairman), the percentage of insider ownership. In addition, two controlled variables have been employed in this study: size of the company and financial leverage.

The results of this study reveal that the size of board of directors is the only variable that has a significant relation with earnings management. The findings of this study have important policy implications since they support encouraging applying corporate governance principles in order to control the behaviors of the board of directors which may lead to distortion in reported financial annual reports. As a result, the reliability and transparency of reported financial statements may be enhanced.
\end{abstract}

Keywords: Earnings management, Corporate Governance, Firm Characteristics, Jordan

\section{Introduction}

The primary objective of financial statements is to provide users with information relating to the uncertainty and timing of future cash flows. Relevance of accounting numbers creates powerful incentives for managers to manipulate earnings to their advantages (Abdul Rahman \& Ali, 2006). Healy and Wahlen (1999) stated two competing reasons for managers to manipulate their income. The first is the capital market pressure which states that the widespread use of accounting information by investors and financial analysts for stock valuation creates incentives for executives to manage earnings in order to influence short-term stock performance. The second reason is contracting motivation which stresses the use of accounting data to monitor and regulate contracts between firms and their stakeholders. Managers can manipulate earnings in order to maximize their income or to signal their private information, thus influencing the informativeness of earnings (Gul et al., 2003). Schipper (1989) and Healy and Wahlen (1999) declared that earnings management is the alternation of performance by insiders to either mislead some stakeholders or to influence contractual outcomes. In other words, managers can work opportunistically for their advantage and disadvantage for their companies. 
Dechow et al. (1996) highlighted that accounting earnings are more reliable and more informative when managers' opportunistic behavior is controlled through a variety of monitoring systems. The bankrupt of large companies has raised serious questions about the effectiveness of different monitoring devices such as external examiner, voluntary disclosure and corporate governance mechanism (Ebrahim, 2007). There has been debate in the literature about the effectiveness of corporate governance factors. Corporate governance implies an explicit responsibility for boards in the financial reporting process. In doing so, it raises the expectation that boards will constrain opportunistic earnings management activities (Epps \& Ismail, 2008). Fama and Jensen (1983) stated that board of directors has important role in protecting shareholder interests by monitoring firm's management team. Based on agency theory framework, outside directors have an incentive to avoid colluding with managers because the value of independent directors' human capital is partially determined by the effectiveness of their monitoring performance (Fama and Jensen, 1983). Otherwise, the value of their human capital as outside directors may diminish. Therefore, outside directors are widely believed to protect the interests of shareholders more effectively. In addition, audit committee serves as a monitor of the financial reporting system. The committee selects the external auditor and questions management, external and internal auditors to determine whether they are acting in the best interest of the company (Blue Ribbon Committee Report)

Although prior work has provided some insight into the role of corporate governance (Klein et al., 2002; Xie et al., 2003; Peasnell et al., 2005), but they have not examined corporate governance mechanism in an environment such as Jordan, where the agency problem is minimized; because most of the companies are family business and so this reduces the probability of earnings management activities. The examination of the level of earnings management in a society like Jordan, where the inclusion of the Jordanian code of corporate governance is just started in January 2009, may therefore contribute to the existing knowledge of earnings management. This study aims to acquire knowledge of whether the existence of corporate governance mechanisms are effective in extenuating earnings management activities among companies listed on the Amman Stock Exchange (ASE).

The remainder of this study is set out as follows: section 2 reviews previous studies and develops hypotheses based on exciting theories. Section 3 presents the research design and describes the data. Section 4, discusses the results. Section 5 provides a summary to the research findings and presents the main conclusions of the study. Moreover, contributions to the literature, limitations, and suggestions for future researches are also presented.

\section{Literature Review and Hypotheses Development}

Prior accounting research has examined the relationship between different corporate governance factors and earnings management (Beasley, 1996; Dechow et al., 1996; Peasnell, et al. 2005). The vast majority of previous studies has concentrated on board and audit committee as proxy for corporate governance mechanism. For example, Klein (2002) found that firms with boards and/or audit committees composed of independent directors are less likely to have larger abnormal accruals. In the same manner, Shen and Chih (2007) found that effective corporate governance mechanism tend to conduct less earnings management. Additionally, Abdul Rahman and Ali (2006) and Epps and Ismail (2008) confirmed that board characteristics are important determinants of earnings management. Bedard et al. (2004) found significant negative relation between measures of earnings management and the all-independent audit committees. However, they found no significant relation between earnings management and audit committee proxied by annual meetings. Cheng and Warfield (2005) investigated whether the propensity for earnings management is lower when management interest's and owners' interests are aligned through higher managerial ownership. Their results confirmed that earnings management is lower for firms with higher managerial ownership.

In the context of Jordan, Al-Fayoumi et al. (2010) examined the relationship between earnings management and ownership structure for the period 2001-2005. The results documented that managers' ownership is ineffective in aligning managers to take value maximizing decisions. Additionally, they found insignificant role for blockholders in monitoring managerial behavior earnings management. Al-khabash and Al-Thuneibat (2009) provided empirical evidence concerning the existence of earnings management from the perspective of external and internal auditors in Jordan, and they believe that managers deal with increasing or decreasing their earnings in order to legitimize their activities.

The current paper concentrates on discussing and analyzing the effects of corporate governance mechanism on earnings management among firms operating in an emerging market. With globalalization of business and financial markets, there has been strong demand for quality of information from firms across countries. By doing so, investors can conduct comparative evaluation of risk and return of firms in different countries (Jaggi and Leung, 2007). At the same time, several numbers of companies are owned by families, such diversity in ownership provides rich 
environment for examination. Hence, several hypotheses are developed that identify and link specific elements of governance to earnings management.

\subsection{Percent of Independent Outside Directors on the Board}

There is a considerable literature regarding the effect of the composition of the board of directors (i.e., inside versus outside directors). Agency theory supports the idea that board independence should be denominated by outside director. Dunn (1987) highlighted that board dominated by outsiders is in a better position to monitor and control managers. Fama and Jensen (1983) argued that the role of the board of directors is to protect shareholder interests by monitoring managers. An important factor that may affect the board's ability to monitor the firm's managers is its composition and the percentage of independent directors on the board.

A number of studies have linked the proportion of outside directors to financial performance and shareholder wealth (e.i., Brickley et al., 1994). Moreover, the dominance of non-executive directors is more effective in monitoring management. Klein (2002), Xie et al. (2003), Sonda et al. (2003) and Peasnell et al. (2005) provided evidence concerning board independence and earnings manipulation and found that companies with independent boards are less likely to report abnormal accruals. Conversely, Park and Shin (2003), Abdul Rahman and Ali (2006) and Osama and Noguer (2007) found no relationship between outsider directors and earnings management.

On the other hand, other studies proposing that completely independent boards may not be effective in monitoring management. For example, Agrawal and Knoeber (1996) found a negative relationship between independent board and firm performance, leading them to conclude that boards that have too many outsiders lose the expertise associated with officers serving on the board. Hence, based on agency theory, it can be hypothesized that:

H1: There is a significant negative relationship between earnings management and proportion of independent directors on the board

\subsection{Board Size}

Board size is viewed as an important element of board characteristics that may affect earnings management (Abdul Rahman and Ali, 2006). The Jordanian code of corporate governance documents that the number of board members has been left to the internal system of the company, although in all cases it should not be less than 5 members and not more than 13 members. Previous studies failed to provide empirical evidence between board size and the effectiveness of monitoring managers. For example, studies of Yermack (1996), Huther (1997) and Andres et al. (2005) indicated that larger board size might be less effective in monitoring management activities. Nevertheless, Dalton et al. (1999) showed that larger board members provide more advantages for their companies through sharing alternative experience which might decrease the incidence of earnings management.

Previous studies have used board size as a determinant of earnings management, but the influence of board size has received mixed results in previous studies. For example, Abdul Rahman and Ali (2006) found a positive relation between earnings management and board size. However, Xie et al. (2003) and Peasnell et al. (2005) found a negative association between earnings management and board size. Interestingly, Abbott et al. (2000) found no relation between quality of earnings and board size. Thus, based on agency theory, it can be hypothesized that:

$\mathrm{H} 2$ : There is a significant negative relationship between earnings management and board size

\subsection{Role Duality}

Consistent with agency theory, the Jordanian corporate governance codes recommend that the role of the chairman should be separated from that of the CEO to ensure that the later would not be in a position with too much power to handle daily business operations. That is, CEO with excessive power over board could easily manipulate income.

The dual office structure also permits the CEO to effectively control information available to other board members and thus impede effective monitoring (Jensen, 1993).However, stewardship theory argues that role duality improve firm performance, because management's compensation is tied to the firm performance.

Previous studies examined the relation between earnings management and role duality. For example, Klein (2002) found that discretionary accrual is positively related to the CEO duality. In contrast, Beasley (1996) documented no significant relation between the likelihood of financial statements fraud and CEO duality. In the same manner, Abdul Rahman and Ali (2006) found that separation between the role of CEO and chairman has no effect on earnings management. Therefore, it can be hypothesized that:

H3: There is a significant positive relationship between earnings management and role duality

\subsection{Concentrated Ownership}

Agency theory suggests that shareholdings held by managers help align their interests with those of shareholders (Jensen and Meckling, 1976). Furthermore, under the convergence-of-interest hypothesis, insider ownership can be 
seen as a mechanism to constrain the opportunistic behavior of managers and, therefore, earnings management is predicted to be negatively associated with insider ownership (Warfield et al., 1995).

Unlike the UK and the US which have dispersed ownership, ownership in Jordanian public listed companies are much more concentrated or owned by family or identifiable group (Al-Fayoumi et al., 2010). Previous studies on earnings management found a negative association between earnings management and insider ownership (Warfield et al., 1995; Chtourou et al., 2001; Abdul Rahman and Ali, 2006). In contrast, Al-Fayoumi et al. (2010) indicated that insiders' ownership is significantly and positively affect earnings management.

H4: There is a significant negative relationship between earnings management and insider ownership

\subsection{Control Variables}

Factors other than corporate governance characteristics may also contribute to earnings management. Therefore, the current study employs two control variables: company size and financial leverage.

\subsubsection{Company Size}

Previous studies indicated negative relation between company size and earnings management (Klein 2002; Xie et al., 2003; Abdul Rahman and Ali, 2006). This support the idea that smaller companies are subject to less control from authority and therefore, managers are more likely engage in earnings management activities. In contrast, Moses (1987) argued that earnings management activities increase as the size of company increase.

\subsubsection{Financial Leverage}

Highly indebted firms may be less able to practice earnings management because they are under close scrutiny of lenders. Bartov et al. (2000) showed that levered companies have more incentive to engage in earnings management activities. DeAngelo et al. (1994) and DeFond and Jiambalvo (1994) found empirical evidence of abnormal accruals when firms face binding debt covenants. Debt covenant violation argument would predict a positive relationship between abnormal accruals and financial leverage. In the same manner, Park and Shin (2003) found that financial leverage is negative and significant related to earnings management

\subsubsection{Industry}

The industry variable measured using a dichotomous variable equal to 1 if the firm $\mathrm{i}$ is listed in industrial sector, and 0 for service sector.

\section{Research Design}

The study examines all industrial and service companies listed on the Amman Stock Exchange (ASE) for the period from 2006 to 2009. The total number of companies listed in ASE in 2009 is 195 companies. The financial companies are excluded from the study, since these companies posses a unique and different working capital structure (Klein, 2002). The exclusion of the financial institutions results in 132 companies. In addition, 31 of which are deleted due to unavailability of annual reports. As well, 15 of which are excluded from the analysis due to insufficient financial data. In addition, 21 outlier observations are deleted before that analysis has been conducted. Thus, the final sample consists of 329 firm-observations for the companies listed on the ASE for the period 2006-2009.

All the data related to corporate governance variables are collected from the annual reports of the sampled firms. Financial data are collected from the Amman Stock Exchange (ASE) database.

\subsection{Variables of the Study}

\subsubsection{Dependent Variable: Earnings Management}

In this study, accounting accruals approach is used to measure earnings management. Accruals Includes a wide range of earnings management techniques available to managers when preparing financial statements, such as accounting policy choices, and accounting estimates (Grace and Koh, 2005; Fields et al., 2001). Accounting accruals is the difference between earnings and cash flows from operating activities. In employing the modified Jones' (1991) model, working capital accrual are decomposed into non-discretionary and discretionary accrual. The majority of previous studies have used abnormal accruals (or discretionary accruals, DA) as a proxy for earnings management. Discretionary accruals are used to demonstrate that managers transfer their accounting earnings from one period to another. That is, discretionary accruals are open to managers' manipulation. Additionally, non-discretionary accruals reflect the non-manipulated accounting accruals items because they are out of managers' control.

The current study uses the cross-sectional modified version of Jones' model (Jones, 1991; and Dechow et al., 1995) to obtain a proxy for discretionary accruals. Dechow et al. (1995) and Guay et al. (1996) argued that the modified Jones 
model is the most powerful model for estimating discretionary accruals among the existing models. Based on the above argument, DA can be measured as follows:

Total accruals as previously mentioned is the difference between earnings and cash flows from operating activities

$$
\text { TACCit }=\text { NIit }- \text { OCFit }
$$

Where:

TACCit $=$ total accruals for company $i$ in year $t$

Nlit $=$ net income before extraordinary items for company $\mathrm{i}$ in year $\mathrm{t}$

OCFit $=$ operating cash flows for company $\mathrm{i}$ in year $\mathrm{t}$

Equation 2 below is estimated for each firm and fiscal year combination

$$
\text { TACCit/ Ait-1 = } \alpha 1(1 / \text { Ait-1 })+\alpha 2(\Delta \text { REVit- } \Delta \text { RECit }) / \text { Ait-1 }+\alpha 3(\text { PPEit } / \text { Ait-1 })+\mathrm{e}
$$

TACCit $=$ total accruals for company $\mathrm{i}$ in year $\mathrm{t}$

Ait-1 = Lagged total asset for company i

$\triangle \mathrm{REVit}=$ change in operating revenues for company $\mathrm{i}$ in year $\mathrm{t}$

$\triangle \mathrm{RECit}=$ change in net receivables for for company $\mathrm{i}$ in year $\mathrm{t}$

PPEit $=$ gross property, plant and equipment for company $\mathrm{i}$ in year $\mathrm{t}$.

$\alpha 1-\alpha 3=$ regression parameters.

$\mathrm{e}=$ error term.

Non-discretionary accruals are measured for each year and fiscal year combination using the equation 3 as follows:

$$
\text { NDTACCit/ Ait-1 = â1(1/ Ait-1) + â2( } \triangle \text { REVit }-\triangle \text { RECit })+ \text { â3 PPEit + e }
$$

NDTACCit $=$ non-discretionary accruals for company $\mathrm{i}$ in year $\mathrm{t}$

Ait-1 = Lagged total asset for company $\mathrm{i}$

$\triangle \mathrm{REVit}=$ change in operating revenues for company $\mathrm{i}$ in year $\mathrm{t}$

$\triangle \mathrm{RECit}=$ change in net receivables for company $\mathrm{i}$ in year $\mathrm{t}$

PPEit $=$ gross property, plant and equipment for company $\mathrm{i}$ in year $\mathrm{t}$

â1 - â3 = regression parameters

The Difference between total accruals and the non-discretionary components of accruals is considered as discretionary accruals (DACC) as stated in equation 4

$$
\text { DACCit }=\text { TACCit }- \text { NDACCit }
$$

DACCit $=$ discretionary accruals for company $\mathrm{i}$ in year $\mathrm{t}$

TACCit $=$ total accruals for company $\mathrm{i}$ in year $\mathrm{t}$

NDTACCit $=$ non-discretionary accruals for company $\mathrm{i}$ in year $\mathrm{t}$

\subsubsection{Independent Variables}

This subsection presents the independent variables and their measurements. Table 1 exhibits the independent variables and their proxies employed in this research.

Insert Table 1 Here

\section{Analysis and Results}

\subsection{Descriptive Results}

This Subsection presents the results of descriptive analysis for the dependent and independent variables.

\subsubsection{Descriptive Results-Dependent Variable}

The descriptive analysis for continues independent variables of the study are presented in Table 2. The descriptive analyses of the earnings management for the sample of the industrial and service sector are shown in Table 3. As presented in Table 3, for industrial sector, the magnitude of absolute value of earnings management in the sample has a small mean 0.078 with standard deviation of 0.06 and the range is from a minimum of 0.0001 to a maximum of 0.319 . This indicates that the deviation between companies is quite small. For service sector, the result shows that 
companies' absolute value of earnings management has a mean of 0.188 and standard deviation of 0.339 and the range is from a minimum of 0.0025 to maximum of 2.158. This indicates that in general, service companies use earnings management activities more than industrial companies.

Insert Table 2. \& Table 3 Here

\subsubsection{Descriptive Results-Independent Variables}

Table 4 exhibits the descriptive analysis for continuous independent variables used in analysis. Table 5 presents the descriptive statistics regarding the firm continuous variables which are included in the model considering the effects of them on earnings management for industrial and service sectors. The results show that on average, number of independent directors in service sector is higher than industrial sector ( 0.36 vs. 0.26$)$. For insider ownership, on average, $24 \%$ of shares owned by insider in industrial sector, whereas $27 \%$ of shares owned by insider directors in service sector. According to board size, for the both sectors, on average number of board size is 9 members. However, the maximum number of board size is 14 members in both sectors, which implies that in general companies do not follow the Jordanian corporate governance codes which recommends that board members should not across 13 members.

Insert Table $4 \&$ Table 5 Here

Table 6 exhibits information regarding dichotomous independent variable, namely, role duality. As shown in Table 6 , for both sectors, industrial and service the result show that companies do not follow the Jordanian corporate governance regulation which recommends companies to separate between $\mathrm{CEO} /$ chairman role.

Insert Table 6 Here

\subsection{Hypotheses Development}

In order to test whether earnings management among Jordanian non-financial companies is significantly associated with variables identified corporate governance characteristics and control variables, a multiple OLS regression analysis is performed using SPSS version 17. Multiple regression assumptions are checked before we run the analysis to ensure that the assumptions are not violated. Table 7 presents the results of multiple OLS-regression analysis. This model is highly significant $(\mathrm{F}=4.17 \mathrm{P}-\mathrm{Value}=0.01)$ with an adjusted $\mathrm{R}^{2} 7.1 \%$, which means that the combinations of the Independent variables explain around $7 \%$ of variation of dependent variables. Specifically, earnings management is found to be related to board size and industry.

Insert Table 7 Here

In order to test the hypotheses of the study, for H1: There is a significant negative relationship between earnings management and proportion of independent directors on the board.

The results document positive but insignificant relation between earnings management and percentage of outsider in board. The results find no support for H1 and for the previous studies such as Klein (2002), Xie et al. (2003), Sonda et al. (2003) and Peasnell et al. (2005). In contrast, this result is consistent with Park and Shin (2003), Abdul Rahman and Ali (2006) and Osama and Noguer (2007).

For H2: There is a significant negative relationship between earnings management and board size. The results document that there is negative and significant relation between earnings management and board size. This result supports H2 and consistent with previous studies (Xie at al., 2003 and peasnell et al., 2005). However, this result is in contradiction to prior studies that have found a positive relationship between earnings management and board size (e.g., Abdul Rahman and Ali, 2006).

For H3: There is a significant positive relationship between earnings management and role duality. The results failed to find any support of H3. This result is consistent with Beasly (1996) and Abdul Rahamn and Ali (2006). Conversely, the result is in an opposition to Klein (2002) who found that role duality is positively related to earnings management.

For the last hypothesis, H4: There is a significant negative relationship between earnings management and insider ownership. The results report no relation between insider ownership and earnings management, which means there is so support for H4. However, this result is in contradiction to prior studies that have found a significant relationship between earnings management and insider ownership (e.g., Warfield et al., 1995; Chtourou et al., 2001; Abdul Rahman and Ali, 2006; Al-Fayoumi et al., 2010).

For the control variables, the results document that nor company's size neither leverage are found to be related earnings management. Nevertheless, the results documents that there is negative and significant relation between earnings management and service sector. 
In order to examine whether the results of the study are sensitive to industry, individual multiple regression analyses are performed for each industry. The results indicate that board size appears to be negative and significant in sectors, industry and service. However, role duality was negative and significant related to earnings management in service sector only. In general, the results of regression models for each industry, tend not to conflict with the conclusion provided by primary analyses of the study.

\section{Conclusion, Limitation and Future Studies}

The objective of this study was to examine the relationship between corporate governance mechanisms and earnings management activities for companies listed on the Amman Stock Exchange (ASE) for the period 2006-2009. The results document no significant relationship between corporate governance factors, with the exception of board size. Corporate governance is viewed in the literature as straightforward agency perspective, and it is sometimes referred to as separation of ownership and control, or separation of finance and management (Shleifer and Vishny, 1997). However, the above assumption may be problematic in an environment such as Jordan, where the agency problem is minimized; since the vast majority of companies owned by identifiable group.

Furthermore, the results show that part of the companies in the study sample do not follow the Jordanian corporate governance regulations, which implies that there is quite low penalties in the case of violation of regulation. Therefore, policy maker should motivate companies to applying corporate governance principles, otherwise they companies should be panelized. The application of corporate governance mechanism is just started in recent years for Jordanian companies, and so they need more time for compliance with the new regulations which may affect the generalizability of our results.

The present study suggests a number of other avenues for future researches. First, the current study examines how corporate governance characteristics affect earnings management. Although field studies and qualitative research methods may raise issues of generalizability, future studies adopting this approach may complement this study by interviewing standard setters and managers to examine the regulation setting process by the former and the motivations for the latter to follow regulations.

Second, this study relies on the view that earnings management activities are undesirable. However, Peasnell et al. (2005) argued that earnings management activities can be viewed as beneficial to shareholder, in particular when earnings management is used in order to improve informativness of reported earnings. Therefore, future research can be conducted to investigate how much earnings management activities are harmful to shareholders.

Third, future research could be conducted for financial companies, where legal and regulatory authorities may play an important role in monitoring managers' activities.

\section{References}

Abbott, L. J., Park, Y., \& Parker, S. (2000). The Effects of Audit Committee Activity and Independence on Corporate Fraud. Managerial Finance, 26(11), 55-67. http://dx.doi.org/10.1108/03074350010766990

Abdul Rahman, R., \& Ali, F. (2006). Board, Audit committee, Culture and Earnings Management: Malaysian Evidence. Managerial Auditing Journal, 21(7), 783-804. http://dx.doi.org/10.1108/02686900610680549

Al-Fayoumi, N., Abuzayed, B., \& Alexander, D. (2010). Ownership Structure and Earnings Management in Emerging Markets: The Case of Jordan. International Research Journal of Finance and Economics, 38, 28-47.

Al-khabash A. A., \& Al-Thuneibat, A. A. (2009). Earnings Management Practices from the Perspective of External and Internal Auditors: Evidence from Jordan. Managerial Auditing Journal, 24(1), 58-80. http://dx.doi.org/doi 10.1108/02686900910919901

Agrawal, A., \& Knoeber, C. R. (1996). Firm Performance and Mechanisms to Control Agency Problems between Manager and Shareholders. Journal of Financial and Quantitative Analysis, 31, 377-89. http://dx.doi.org/10.2307/2331397

Andres, P. D., Azofra, V., \& Lopez, F. (2005). Corporate Boards in OECD Countries: Size, Composition, Functioning and Effectiveness. Corporate Governance: An International Review, 13(2), 197-210. http://dx.doi.org/10.1111/j.1467-8683.2005.00418.x.

Bartov, E., Gul, F. A., \& Tsui, J. S. L. (2000). Discretionary-Accruals Models and Audit Qualifications. New York: Working Paper, New York University.

Beasley, M. S. (1996). An Empirical Analysis of the Relation between the Board of Director Composition and Financial Statement Fraud. The Accounting Review, 71(4), 443-465. 
Bedard, J., Chtourou, S., \& Courteau, L. (2004). The Effect of Audit Committee Expertise, Independence, and Activity on Aggressive Earnings Management, Auditing: A Journal of Practice and Theory, 23(2), 13-35. http://dx.doi.org/10.2308/aud.2004.23.2.13

Brickley, J. A., Coles, J. L., \& Terry, R. L. (1994). Outside Directors and the Adoption of Poison Pills. Journal of Financial Economics, 35, 371-390. http://dx.doi.org/10.1016/0304-405X(94)90038-8

Cheng, Q., \& Warfield, T. (2005). Equity Incentives and Earnings Management. The Accounting Review, 80, 441-477. http://dx.doi.org/10.2308/accr.2005.80.2.441

Chtourou, S. M., Bedard, J., \& Courteau, L. (2001). Corporate Governance and Earnings Management. Working Paper, University of Laval Canada.

Dalton, D. R., Daily, C. M., Johnson, J. L., \& Ellstrand, A. E. (1999). Number of Directors and Financial Performance: A Meta Analysis. Academy of Management Journal, 42(6), 674-686. http://dx.doi.org/10.2307/256988

DeAngelo, H., DeAngelo, L., \& Skinner, D. J. (1994). Accounting Choice in Troubled Companies. Journal of Accounting and Economics, 17, 113-144. http://dx.doi.org/doi:10.1016/0165-4101(94)90007-8

Dechow, P. M., Sloan, R. G., \& Sweeney, A. P. (1995). Detecting Earnings Management. The Accounting Review, 70(2), 193-225.

Dechow, P., Sloan, R. G., \& Sweeney, A. (1996). Causes and Consequences of Earnings Manipulations: An analysis of Firms Subject to Enforcement Actions by the SEC. Contemporary Accounting Research, 13,1-36. http://dx.doi.org/doi:10.1111/j.1911-3846.1996.tb00489.x

DeFond, M. L., \& Jiambalvo, J. (1994). Debt Covenant Violation and the Manipulation of Accruals. Journal of Accounting and Economics, 17, 145-176. http://dx.doi.org/10.1016/0165-4101(94)90008-6

Dunn, D. J. (1987). Directors Aren’t Doing their Jobs, Fortune, March, 117-119.

Ebrahim, A. (2007). Earnings Management and Board Activity: An Additional Evidence. Review of Accounting and Finance, 6(1), 42-58. http://dx.doi.org/10.1108/14757700710725458

Epps R. W., \& Ismail, T. H. (2008). Board of Directors' Governance challenges and Earnings Management. Journal of Accounting \& Organizational Change, 5(3), 390-416. http://dx.doi.org/doi 10.1108/18325910910986981

Fama, E. F., \& Jensen, M. C. (1983). Separation of Ownership and Control, Journal of Law and Economics, 26, 301-325. http://dx.doi.org/10.1086/467037

Fields, T., Lys T., \& Vincent, L. (2001). Empirical Research on Accounting Choice. Journal of Accounting \& Economics, 31, 255-307. http://dx.doi.org/10.1016/S0165-4101(01)00028-3

Grace, H., \& Koh, P. (2005). Does the Presence of Institutional Investors Influence Accruals Management? Evidence from Australia. Corporate Governance, 13, 809-823. http://dx.doi.org/10.1111/j.1467-8683.2005.00472.x

Guay, W. R., Kothari, S.P., \& Watts, R. L. (1996). A Market-based Evaluation of Discretionary Accruals Models. Journal of Accounting Research, 34, 83-105. http://dx.doi.org/10.2307/2491427

Gul, F. A., Chen, C. J. P., \& Tsui, J. S. L. (2003). Discretionary accounting accruals, managers' incentives, and audit fees. Contemporary Accounting Research, 20, 441-464. http://dx.doi.org/10.1506/686E-NF2J-73X6-G540

Healy, P., \& Wahlen, J. (1999). A Review of the Earnings Management Literature and Its Implications for Standard Setting. Accounting Horizons, 13, 365-383. http://dx.doi.org/10.2308/acch.1999.13.4.365

Huther, J. (1997). An Empirical Test of the Effect of Board Size on Firm Efficiency. Economics Letters, 54, PP. 259-264. http://dx.doi.org/10.1016/S0165-1765(97)00035-9

Jensen, M. (1993). The Modern Industrial Revolution, Exit, and the Failure of Internal Control Systems. Journal of Finance, 48, 831-880. http://dx.doi.org/10.2307/2329018

Jensen, M., \& Meckling, W. (1976). Theory of the Firm: Managerial Behavior, Agency Costs and Ownership Structure. Journal of Financial Economics, 3, 305-360. http://dx.doi.org/10.1016/0304-405X(76)90026-X

Jones, J. (1991). Earnings Management during Import Relief Investigations. Journal of Accounting Research, 29(2), 193-228. http://dx.doi.org/10.2307/2491047

Klein, A. (2002). Audit Committee, Board of Directors' Characteristics, and Earnings Management. Journal of Accounting and Economics, 33(3), 375-400. http://dx.doi.org/10.1016/S0165-4101(02)00059-9

Moses, O. D. (1987). Income Smoothing and Incentives: Empirical Tests Using Accounting Changes. The Accounting Review, 4, 358-377. 
Osma, B. G., \& Noguer, B. G. (2007). The Effect of the Board Composition and its Monitoring Committees on Earnings Management: Evidence from Spain. Corporate Governance An International Review, 15(6), 1413-1428. http://dx.doi.org/10.1111/j.1467-8683.2007.00654.x

Park, W. Y., \& Shin, H. H. (2003). Board composition and earnings management in Canada. Journal of Corporate Finance, 185, 1-27. http://dx.doi.org/10.1016/S0929-1199(03)00025-7

Peasnell, K. V., Pope, P. F., \& Young, S. (2005). Board Monitoring and Earnings Management: Do Outside Directors Influence Abnormal Accruals? Journal of Business Finance \& Accounting, 32, 1311-46. http://dx.doi.org/10.1111/j.0306-686X.2005.00630.x

Shen, C-H., \& Chih, H-L. (2007). Earnings Management and Corporate Governance in Asia's Emerging Markets. 15(5), 999-1021.

Schipper, K. (1989). Commentary on Earnings Management. Accounting Horizons, 3, 91-102.

Shleifer, A., \& Vishny, R.W. (1997). Large Shareholders and Corporate Control. Journal of Political Economy, 94(3), 461-488. http://dx.doi.org/10.1086/261385

Sonda M. C., Bedard, J., \& Courteau, L. (2003). Corporate Governance and Earnings Management. Working Paper, http/paper.ssrn.com.

Xie, B., Davidson, N. W., \& DaDalt, P. (2003). Earnings Management and Corporate Governance: The Roles of the Board and the Audit Committee. Journal of Corporate Finance, 9(3), 295-316. http://dx.doi.org/10.1016/S0929-1199(02)00006-8

Yermack, D. (1996). Higher Market Valuation of Companies with A Small Board of Directors. Journal of Financial Economics, 40, 185-2. http://dx.doi.org/10.1016/0304-405X(95)00844-5

Warfield, T. D., Wild, J. J., \& Wild, K. L. (1995). Managerial Ownership, Accounting Choices and Informativeness of Earnings. Journal of Accounting and Economics, 20, 61-91. http://dx.doi.org/10.1016/0165-4101(94)00393-J

Table1. Independent Variables and their Measurements

\begin{tabular}{|l|l|l|}
\hline Independent Variables & Code & Proxies \\
\hline $\begin{array}{l}\text { Proportion of independent } \\
\text { directors }\end{array}$ & BIND & Number of independent non-executive directors to total number of board members \\
\hline Board size & BOARD & Total number of board members \\
\hline Role Duality & DUALITY & $\begin{array}{l}\text { A dichotomous variable equal to } 0 \text { if the firm i is separated between the role of CEO and Chairman, } \\
\text { and } 1 \text { otherwise. }\end{array}$ \\
\hline Concentrated ownership & INSIDER & The percentage of shares held by officers or directors within the company. \\
\hline Control Variables & SIZE & The natural logarithm of total asset \\
\hline Company size & LEV & Total debt to total assets. \\
\hline Financial leverage & INDUST & $\begin{array}{l}\text { The industry variable measured using a dichotomous variable equal to } 1 \text { if the firm i is listed in } \\
\text { industrial sector, and } 0 \text { for service sector. }\end{array}$ \\
\hline Industry & &
\end{tabular}

Table 2. Descriptive Analysis for Earnings Management-Pooled Data

\begin{tabular}{|l|l|l|l|l|}
\hline Sector & Mean & Std. Deviation & Minimum & Maximum \\
\hline Earnings Management & 0.133 & 0.197 & 0.0001 & 2.158 \\
\hline
\end{tabular}

Table 3. Descriptive Analysis for Earnings Management Classified by Industry

\begin{tabular}{|l|l|l|l|l|}
\hline Sector & Mean & Std. Deviation & Minimum & Maximum \\
\hline Industrial & 0.078 & 0.060 & 0.319 & 0.0001 \\
\hline Service & 0.188 & 0.339 & 2.158 & 0.0025 \\
\hline
\end{tabular}


Table 4. Descriptive Analysis for Earnings Management-Pooled Data

\begin{tabular}{|l|l|l|l|l|}
\hline Variables & Mean & Std. Deviation & Minimum & Maximum \\
\hline BIND & 0.31 & 0.32 & 0 & 1 \\
\hline BOARD & 9.11 & 2.25 & 0 & 14 \\
\hline INSIDER & 71 & 0.47 & 0 & 71 \\
\hline
\end{tabular}

Table 5. Descriptive Analysis for Continuous Independent Variables

\begin{tabular}{|c|c|c|c|c|c|c|c|c|}
\hline \multirow{2}{*}{$\begin{array}{l}\text { Variables } \\
\text { Sector }\end{array}$} & \multicolumn{2}{|l|}{ Mean } & \multicolumn{2}{|c|}{ Std. Deviation } & \multicolumn{2}{|l|}{ Maximum } & \multicolumn{2}{|l|}{ Minimum } \\
\hline & Industrial & Service & Industrial & Service & Industrial & Service & Industrial & Service \\
\hline BIND & 0.26 & 0.36 & 0.29 & 0.33 & 1 & 1 & 0 & 0 \\
\hline INSIDER & 0.24 & 0.27 & 0.20 & 0.26 & 0.95 & 0.71 & 0 & 0 \\
\hline BOARD & 9.009 & 8.994 & 0.29 & 2.36 & 14 & 14 & 5 & 5 \\
\hline
\end{tabular}

Table 6. Descriptive Analysis for Role Duality

\begin{tabular}{|l|l|l|}
\hline Sector & Frequency & \% of Frequency \\
\hline Industrial & 32 & 14.5 \\
\hline Service & 39 & 21 \\
\hline
\end{tabular}

Table 7. The Results of Multiple Regression Analyses of Earnings Management

\begin{tabular}{|l|l|l|l|}
\hline Variables & Coefficients & t-statistic & P-Value \\
\hline Intercept & 0.078 & 2.222 & $.027 * *$ \\
\hline BIND & 0.007 & 0.789 & 0.430 \\
\hline BOARD & -0.003 & -1.967 & $.050 * *$ \\
\hline DUALITY & 0.003 & 0.379 & 1.099 \\
\hline INSIDER & 0.000 & 0.482 & 1.245 \\
\hline LEV & 0.000 & -1.001 & 1.110 \\
\hline SIZE & 0.002 & 0.378 & 1.020 \\
\hline INDUST & -0.18 & -3.026 & 0.317 \\
\hline Adjusted R2 & 0.071 & 0.706 \\
\hline Model F Test & 4.17 P-value $=.01$ & 1.310 \\
\hline
\end{tabular}

$* *$ Significant at the $5 \%$ level $*$ Significant at the $10 \%$ level 